\title{
A CRITICAL APPRAISAL OF DISMISSALS AT THE BEHEST OF A THIRD PARTY: THE IMPACT OF THE CONSTITUTIONAL LABOUR RIGHTS
}

\author{
Tumo Charles Maloka \\ $B A$ LLB LLM LLD \\ Associate Professor, University of Limpopo
}

\section{SUMMARY}

The pivotal judgments on dismissals at the behest of a third party - East Rand Proprietary Mines Ltd $v$ UPUSA, ${ }^{1}$ Lebowa Platinum Mines $v$ Hill, ${ }^{2}$ NUMSA $v$ Hendor Mining Supplies a Division of Marschalk Beleggings (Pty) Ltd ${ }^{3}$ TSI Holdings (Pty) Ltd $\checkmark$ NUMSA, ${ }^{4}$ NUPSAW obo Mani v National Lotteries Board ${ }^{5}$ and NUMSA v High Goal Investments t/a Chuma Security Services ${ }^{6}$ - deeply implicate discrimination in all its manifestations, accountability, gendered precariousness and social justice. This contribution explores the focal questions raised in recent times concerning the fairness of a dismissal at the instance of a third party. First, there are fundamental points relating to the constitutional and statutory protection of security of employment. Secondly, there are those familiar problems often associated with substantive and procedural fairness that surface here under the guise of questioning the disciplinary power of the employer. In this context, inroads into managerial prerogative and disciplinary procedure are amplified where there has been no fault on the part of the employee and no breakdown of the trust relationship, or where the employee has been disciplined, but not dismissed and the employer did not want to terminate the employee's employment but was coerced by the third party to do so. Thirdly, there is the thorny issue of the reason behind the third-party demand and the related issue of intolerability caused by the targeted employee. And finally, there is the issue of striking in support of a demand for dismissal of a co-employee.

\section{INTRODUCTION}

A third party's steadfast demand that a co-employee be dismissed is one of the most intractable problems that may confront modern management. ${ }^{7}$

(1996) 27 ILJ 1135 (LAC) (ERPM).

(1998) 19 ILJ 1112 (LAC) (Lebowa Platinum Mines).

[2007] ZALC 26 (Hendor Mining Supplies).

[2006] 7 BLLR 631 (LAC) (TSI Holdings).

2014 (3) SA 544 (CC) (National Lotteries Board).

[2016] ZALCCT 34 (Chuma).

The fallout surrounding the Clicks/TRESemme online advertisement is a textbook illustration. The Economic Freedom Fighters' demands included that all the companies, Clicks managers, directors and employees involved in making the advertisement be 
Faced with a catch-22 situation, an employer is caught in an invidious position. On the one hand, the employer is expected to make persistent efforts to persuade the third party to drop the demand for dismissal of a coemployee. On the other hand, the employer is expected to exhaust all alternatives to dismissal, taking into account the injustice likely to be suffered by the targeted employee.

It is only in relatively recent years that a significant body of case law dealing with fairness of dismissal in response to third-party pressure has begun to be generated. The decision of the Labour Court in Chuma ${ }^{8}$ following hot on the heels of National Lotteries Board ${ }^{9}$ sets the tone of this inquiry into the impact of constitutional labour rights. The interesting, and in some respects disconcerting, body of jurisprudence concerning dismissals at the instance of a third party is constructed around a series of cases: ERPM, ${ }^{10}$ Lebowa Platinum Mines, ${ }^{11}$ Hendor Mining Supplies ${ }^{12}$ and TSI Holdings (Pty) Ltd. ${ }^{13}$ Examining the evolving jurisprudence on the fairness of dismissals at the instance of a third party is important because it is a fruitful site for appraisal of the extent to which South Africa has come to grips with the complexities of employment vulnerability. Issues raised by dismissals at the instance of a third party clearly implicate the rights to dignity and equality, and how intolerability and gendered precariousness in the workplace might affect the right to fair labour practices.

\section{THE NATURE OF DISMISSAL AT THE BEHEST OF A THIRD PARTY}

A dismissal at the instance of a third party shares facial similarities with incompatibility ${ }^{14}$ in the sense that it assumes almost infinite diversity of

dismissed with immediate effect and their names made public. See "EFF Gives Clicks Until Saturday to Meet Its List of Demands" (5 September 2020) https://www.sabcnews.com/ sabcnews/eff-gives-clicks-until-saturday-night-to-meet-list-of-demands/ (accessed 2020-09 07); Mthombothi "Idiocy Was Mind-Boggling, but SA Will Regret Clicks Making Common Cause With Thuggery" (2020-09-13) Sunday Times and Wilson "Unilever Must Do More" (2020-09-13) Sunday Times.

8 Supra.

9 Supra.

10 Supra.

11 Supra.

12 Supra.

13 Supra.

14 Grogan Dismissal (2002) 279-280 points out that "[d]ismissals at the behest of third parties are more closely akin to classic dismissal for operational reasons than dismissal for incompatibility, because the tension arising from the employee's continued presence cannot be alleviated even if the employees concerned adapt their conduct. However, the two classes of dismissal may shade into each other because the employees' demand that offending employees be dismissed may be caused by the latter's unacceptable conduct. However, the distinguishing aspect of dismissal at the instance of third parties is that, had it not been for the pressure exerted by the third party, the employer would not have dismissed the employee. Such dismissals are effected because employers regard the cost of keeping offending employees on their payroll as outweighed by the actual or potential costs of the third parties' reaction if the employees are not dismissed." In Zeda Car Leasing (Pty) Ltd t/a Avis Fleet $v$ Van Dyk [2020] ZALAC 4, incompatibility formed the basis of dismissal for operational requirements. 
forms. ${ }^{15}$ The most prevalent form of dismissal at the instance of a third party arises when there is a termination of an employee's services by a client of a temporary employment service. ${ }^{16}$ The delicate nature of the relationship between a client and a temporary employment service is emblematic of the rampant abuse of workers in many jurisdictions. ${ }^{17}$ Compounding precariousness is the pervasive issue of sham arrangements. ${ }^{18}$ The persistent problems around triangular employment relationships ${ }^{19}$ also reflect on the elusiveness of the ILO's quest for decent work. ${ }^{20}$

It is trite that in appropriate circumstances the intolerability of a continued employment relationship can rightfully justify dismissal. ${ }^{21}$ This is consistent with the proposition that business risk is "predominantly based on the trustworthiness of company employees and that the accumulation of individual breaches of trust has significant economic repercussions". ${ }^{22}$ In the context of third-party pressure for dismissal for intolerability, the leitmotif has

15 The most intriguing and unusual example is provided by the unreported case discussed by Marais "Bad Smell Leads to Fair Dismissal of Employee" (2004-02-25) Cape Argus. There the employer's dilemma emanated from the unpleasant body odour of one of its female employees. The reason for this body odour was not known, although co-workers alleged that it came from "something that she smears on herself"'. The employee had 15 years' service, a clean disciplinary record and was an excellent worker. The employee was a trade union member and the company, with the shop stewards and later the union officials had tried to deal with the smelly situation for nine months. The shop stewards tried to discuss the situation with the employee but she would not acknowledge any problem or smelly condition. The employer, with the union's consent followed a two-pronged approach, dealing with the matter in terms of the procedural requirement of an incapacity dismissal and of an operational requirements dismissal. The employee's services were terminated owing to her "incapacity", making her "redundant" to the "employer's operational requirements". The union agreed by means of a signed collective agreement.

16 See Geldenhuys "The Effect of Changing Public Policy on the Automatic Termination of Fixed-Term Employment Contracts in South Africa" 201720 PER/PELJ 1; Cohen "Legality of the Automatic Termination of Contract of Employment" 201132 Obiter 665.

17 ILO Convention concerning Private Employment Agencies C181 of 1997 (adopted 1997, came into force 10 May 2000); ILO Recommendation 198. See generally Fudge and Strauss (eds) Temporary Work, Agencies and Unfree Labour: Insecurity in the New World of Work (2015); Leighton and Wynn "Classifying Employment Relationships: More Sliding Doors or a Better Regulatory Framework?" 201140 ILJ (UK) 5.

18 For a textbook illustration of artificial arrangements, see Dyokhwe $v$ Coen de Kock NO (2012) 33 ILJ 2401 (LC); Building Bargaining Council (Southern \& Eastern Cape) v Melmons Cabinet CC [2001] 3 BLLR 329 (LC). For a helpful analysis, see Cohen "Debunking the Legal Fiction: Dyokhwe v De Kock NO \& Others" 201233 ILJ 2318 and Cohen "Placing Substance Over Form: Identifying the True Parties to an Employment Relationship" 200829 ILJ 87.

19 Theron "Prisoners of a Paradigm: Labour Broking, the 'New Services' and Non-Standard Employment" in Le Roux and Rycroft (eds) Reinventing Labour Law: Reflecting on the First 15 Years of the Labour Relations Act and Future Challenges" (2012) 50.

20 Hepple "Equality and Empowerment for Decent Work" 2001140 ILR 5; Van Eck "Revisiting Agency Work in Namibia and South Africa: Any Lessons From Decent Work Agenda and Flexicurity Approach?" 201430 IJCLLIR 49.

21 Illustrative is the breakdown of the trust relationship in Masetha $v$ President of the RSA 2008 (1) SA 566 (CC), Moyane v Ramaphosa [2019] 1 All SA 718 (GP), Gama v Transnet (SOC) Ltd [2018] ZALCJHB 452 and Old Mutual v Moyo [2020] ZAGPJHC 1. See also Rycroft "The Intolerable Relationship" 201233 ILJ 2271.

22 Miyambo v CCMA [2010] 10 BLLR 1017 (LAC) par 13; De Beers Consolidated Mines v CCMA [200] 9 BLLR 995 (LAC) par 22. 
been the use of racial slurs. ${ }^{23}$ The Lebowa Platinum Mines principles ${ }^{24}$ are generally applied in determining the substantive fairness of a dismissal in response to a demand by a third party.

\section{EAST RAND PROPRIETARY MINES LTD V UPUSA (ERPM) ${ }^{25}$}

The issues put before Cameron JA (as he then was) in ERPM concerned a situation where mass dismissal of employees of one ethnic group was effected to placate the demand of another. The circumstances surrounding the demand by a section of the workforce for the dismissal of employees belonging to another ethnic group are aptly captured with customary lucidity:

"[t]he concerned employees addressed a letter to the general manager of ERPM. It asked of management an answer to the following question: 'Are the employees have the right to dismiss other employees just because they don't want them?' [sic] No amount of verbal elaboration or supposed legal sophistication can express more powerfully the question a dismissal at behest of a third party raises." 26

This graphically underscores a difficult problem in fair employment practice when an employer faces a demand for dismissal by a third party. To make things worse, the demand for the dismissal of the targeted employees was predicated on an illegitimate foundation. ${ }^{27}$ Put bluntly, it amounted to

23 See e.g., Lebowa Platinum Mines supra; Kroeger v Visual Marketing (2003) 24 ILJ 1979 (LC) (Kroeger); Govender v Mondi Kraft-Richards Bay (1999) 20 ILJ 2881 (LC) (Govender); TSI Holdings supra; Hendor Mining Supplies supra. See also Botha "Managing Racism in the Workplace" 2018 THRHR 671; Khumalo "Racism in the Workplace: A View From the Jurisprudence of Courts in the Past Decade" 201830 SA Merc LJ 377; Thabane and Rycroft "Racism in the Workplace" 200829 ILJ 43. Recent cases of aversive workplace racism include: Rustenburg Platinum Mines v SAEWA obo Bester (2018) 39 ILJ 1503 (CC); Duncanmec (Pty) Ltd v Gaylard NO (2018) 39 ILJ 2633 (CC); SARS v CCMA (2017) 38 ILJ 97 (CC).

24 Kroon JA in Lebowa Platinum Mines supra 671-673 formulated the following principles:

- the mere fact that a third party demands the dismissal of an employee does not render such dismissal fair;

- the demand for the employee's dismissal must have good and sufficient foundation;

- the threat of action by the third party if its demand was not met had to be real or serious;

- the harm that would be caused if the third party were to carry out its threat must be substantial - mere inconvenience is not enough to justify dismissal;

- the employer must make reasonable efforts to dissuade the party making the demand to abandon the demand - if the third party cannot be persuaded to drop the demand, the employer must investigate and consider the alternatives to dismissal; and

- $\quad$ in the process of considering alternatives, the employer must consult the employee and make it clear to him or her that the rejection of any possible alternative will result in dismissal.

25 Supra.

26 ERPM supra 1150D (emphasis added).

27 In De Doorns, locals demanded dismissals of mainly Zimbabwean nationals. See Misago Violence, Labour and the Displacement of Zimbabweans in De Doorns, Western Cape 2009 Issue Brief 2 African Centre for Migration \& Society: University of Witwatersrand http://migration.org.za (accessed 2018-03-18); Visser Farm Workers' Living and Working Conditions in South Africa: Key Trends, Emergent Issues, and Underlying and Structural Problems ILO (2015). 
discrimination on the basis of ethnicity impinging upon the affected employees' human dignity. If the demand does not enjoy legitimate foundation, there must be special considerations that exist to sustain such dismissals. The learned judge explained:

"Where a dismissal is actuated by operational reasons which arise from ethnic or racial hostility, the court will in my view countenance the dismissal only where it is satisfied that management not only acted reasonably, but it had no alternative to dismissal ... In a country that consists of linguistic, ethnic and other minorities, public policy ... requires that a test of necessity, and not reasonableness, should be applied in scrutinising management's action in dismissing workers in such circumstances."28

ERPM and CWIU $v$ Boardman Bros (Pty) Ltd ${ }^{29}$ are different sides of the same coin. Boardman Bros concerned the dismissal of black workers following illegal industrial action that was triggered by the recruitment of coloured employees. The black workers had demanded that coloured workers be dismissed. In an appeal against their dismissal, the workers contended that, although their strike was illegal, it was justified because of the fear that their job security was in jeopardy as a result of the change in recruitment policy.

The Industrial Court found that the fears of black workers that the introduction of coloured employees would lead to their dismissal were unfounded. Maritz AM felt that their discontent was understandable, but not morally defensible. In upholding the fairness of the dismissals, it was stressed that the striking workers' stance was unjustified and that their demand enjoyed no legitimate foundation.

\section{THE CORPORATE GOVERNANCE MIGRAINE AND WORKERS' DEMANDS FOR ACCOUNTABILITY}

Unlike the outright bigotry displayed in ERPM and Boardman Bros, in National Lotteries Board ${ }^{30}$ the demand for the board to dismiss the CEO resonated with the foundational constitutional tri-norms of accountability, responsiveness and openness. ${ }^{31}$ Moreover, the demand touched on corporate governance angst. ${ }^{32}$ The piercing truth was eloquently delivered by Professor Njabulo Ndebele during the Mandela Centenary Lecture. Ndebele castigated those public officials who, "by wilful intent, cause the propeller of the state to stop spinning in mid-air". ${ }^{33}$ In the present context, the

28 ERPM supra $1151 \mathrm{~B}$ and $\mathrm{F}-\mathrm{G}$.

29 (1991) 12 ILJ 864 (IC) (Boardman Bros).

30 Supra.

31 President of RSA v SARFU 2001 (1) SA 1 (CC) par 133. See also Okpaluba "The Constitutional Principle of Accountability: A Study of Contemporary South African Case Law" 201833 SAPL 1.

32 Thabane and Snyman-Van Deventer "Pathological Corporate Governance Deficiencies in South Africa's State-Owned Companies: A Critical Reflection" 201821 PER/PELJ 1.

33 Klaas "Failure to Face Tribal Strongmen Will Be Cyril's Downfall" (2018-07-22) IOL https://www.msn.com/en-za/news/editorpicks/failure-to-face-tribal-strongmen-will-becyril\%E2\%80\%99s-downfall/ar-BBKVH4W?li=AAaxc0E\&ocid=spartanntp (accessed 201807-24). 
employees, through their shop stewards, had addressed a letter to the Board raising grievances about the leadership of the Board's CEO: "the employees said they had 'suffered adversely under [the CEO's] bureaucratic leadership style and his inept management approaches."'34 In this regard, they sought information about the CEO's terms of contract from the employer. ${ }^{35}$ The employer refused to disclose them.

Unconvinced with the Board's response, they referred the matter to the CCMA. During the conciliation processes, the employees wrote a letter containing various allegations against the CEO. This letter was leaked to a national newspaper. Subsequently, the employees addressed a petition to the Board making further allegations against the CEO, and passing a vote of "no confidence" in him. The conciliation process was not resolved. The employer warned that if the petition was not withdrawn it would institute disciplinary proceedings. When some employees refused to withdraw the petition, the employer instituted disciplinary proceedings. During this process, the employees were offered another opportunity to withdraw their names from the petition and be issued with written warnings. The employees chose not to withdraw their names and were subsequently dismissed.

The employees unsuccessfully challenged their dismissals in the Labour Court. In challenging the dismissals, the union's cresting argument was that the dismissals were automatically unfair because the employees' conduct constituted participation in the lawful activities of the union. ${ }^{36}$ In the alternative, it was submitted that even if the dismissals were not automatically unfair, they were nevertheless substantively unfair.

The Labour Court found that, although a union may vigorously pursue the rights of its members, the right to freedom of expression does not afford a union and its members the right to engage, without consequences, in acts of gross insubordination. The employees did not prevail in their appeal to the Supreme Court of Appeal, ${ }^{37}$ which unanimously found that the cause of their dismissal was the offensive content they had communicated in the petition, not the act of petitioning itself.

The Constitutional Court reversed the judgment of the Supreme Court of Appeal. In the majority judgment, the court held that the statements made by the employees were in pursuit of the ongoing statutory conciliation process, and in the exercise of their rights to participate in collective bargaining. Zondo $\mathrm{J}$ found that the employees' conduct constituted lawful activities of a union. Their dismissals were accordingly automatically unfair. Furthermore, the failure to use the statutory dispute-resolution mechanisms or to table their grievances internally did not render them guilty of insubordination. In the result, the Board was ordered to reinstate the employees.

$34 \quad$ National Lotteries Board supra par 114.

35 National Lotteries Board supra par 4 and 109-113.

36 Ss $5(2)(b)$ and $5(2)(c)($ iv) of the LRA. National Lotteries Board supra par 28-30 and 136-149.

37 NUPSAWU obo Mani v National Lotteries Board (2014) 34 ILJ 1885 (SCA). 


\section{STRIKING IN SUPPORT OF A DEMAND THAT A CO-EMPLOYEE BE DISMISSED?}

The question whether employees can embark upon a collective refusal to work in support of a demand that another employee be dismissed brings to the fore the fairness or otherwise of a dismissal at the behest of a third party. Section 23 of the Constitution, ${ }^{38}$ as amplified by sections 185 and 64 of the Labour Relations Act ${ }^{39}$ (LRA), provide the anvil upon which the details will be beaten in order that a clear position can emerge.

There can be no doubt that to demand an employee's dismissal without a fair hearing is unlawful - as is a situation where a third party insists on dismissal of an employee who has been disciplined but not dismissed. Can management review the outcome of the disciplinary hearing in order to placate those demanding the dismissal of their fellow employee? Put another way, can the employer proceed against the employee twice over for the same offence? This takes us back to the complex problem of double jeopardy ${ }^{40}$ or duplicated disciplinary hearings. ${ }^{41}$ Whether a second disciplinary enquiry may be opened against an employee depends on whether it is, in all circumstances, fair to do so. ${ }^{42}$ The paramount consideration, however, is fairness to both sides. ${ }^{43}$ Subjecting an employee to a second disciplinary hearing and dismissing him or her so as to assuage a third party would certainly be unfair and amount to double jeopardy. In sum, it would be wrong for an employer to overrule the decision of a presiding officer in response to a coercive third party demand.

Intolerability of an employee in Hendor Mining Supplies ${ }^{44}$ was triggered by a supervisor's alleged racial and degrading utterances. The supervisor was disciplined and a final written warning was issued. Unfortunately, however, the disciplinary enquiry was a sham. It left the employees unsatisfied, bitter and still disgruntled. They subsequently embarked on a work stoppage. Despite attempts by the union to resolve the dispute, the employees were dismissed as a consequence of their unlawful conduct. Subsequently, an agreement was reached in terms of which the employees were reinstated on a final warning and on condition that they undertook to report to the supervisor. Notwithstanding the agreement, the employees persisted with the demand that the supervisor's services be terminated.

\footnotetext{
Constitution of the Republic of South Africa, 1996 (Constitution).

66 of 1995.

40 This concept was developed by the United States Supreme Court based on the interpretation of the Fifth Amendment to the American Constitution. See e.g., Barktus v Illinois 359 US 121 1959; Benton v Maryland 395 US 784 1969. The constitutional proscription on double jeopardy is enshrined in $\mathrm{S} 35(3)(\mathrm{m})$ of the 1996 Constitution. For a detailed analysis, see $S \vee$ Basson 2005 (1) SA 171 (CC) par 61-69.

41 Le Roux "Can Employers Review the Outcomes of Disciplinary Proceedings?" 2016 25(7) CLL 70; Grogan 'Double Jeopardy: Are Duplicated Disciplinary Inquiries Allowed?' 2000 16(1) EL 15

$42 B M W(S A)$ (Pty) Ltd $v$ Van der Walt (2000) 21 ILJ 113 (LAC) par 21

43 Woolworths (Pty) Ltd $v$ Whitehead (2000) 21 ILJ 571 (LAC) 599H-I.
}

44 Supra. 
Management's stance was that there was no dispute as the dispute regarding the supervisor had been resolved by the agreement that had reinstated the employees on condition that they report to the supervisor. The employer issued an ultimatum to the effect that the striking employees would be dismissed if they failed to return to work. After the union could not obtain an interdict restraining the employer from dismissing employees, ${ }^{45}$ they tendered their services. They also withdrew their demands in regard to the supervisor. Management reciprocated by declining the tender and by suspending them on full pay. Following disciplinary proceedings, the employees were dismissed.

The Labour Court noted that the strike was conducted in a peaceful manner. Moreover, the strikers tendered services as soon as they come to the realisation that their interdict application was dismissed. Cele $\mathrm{J}$ reinstated the employees reasoning that the unfairness of the enquiry against the supervisor rendered subsequent dismissals unfair. ${ }^{46}$

TSI Holdings ${ }^{47}$ did not settle the question whether a work stoppage in support of a demand for the dismissal of a manager would be protected where the dismissal would not infringe the targeted employee's right not to be dismissed unfairly. As a consequence of threats of industrial action, the employer suspended the manager with full benefits for alleged use of foul language against staff. The suspension was "pending the outcome of negotiations and legal proceedings to be held". ${ }^{48}$ It was contended by the appellant that the demand for the manager's dismissal was unlawful and a strike made up of a concerted refusal to work in support of an unlawful demand could not be a protected strike. The union countered by pointing out that the strike's purpose was to get the employer to subject the manager to a fair disciplinary process. More importantly, the employees were willing to accept whatever outcome would flow from a fair disciplinary process. In turn, the employer drew attention to the fact that, when it suspended the manager and asked the union also to suspend the strike, it refused to do so.

The Labour Appeal Court found that the concerted refusal at hand is one that had a demand - namely, to compel the employer to dismiss the offending manager. ${ }^{49}$ It followed that the union cannot plausibly argue that this was a strike where no demand has been articulated. The next question that fell to be determined was whether such a demand was an unlawful one. Although the learned judge declined to provide a categorical answer, it is nonetheless safe to assume that it is permissible for employees to engage in a concerted refusal to work in support of a demand that an employer dismiss an employee fairly. Zondo JP elaborates:

"I have in mind the case of an employee who has been charged with, and found guilty of, misconduct that is sufficiently serious to render his dismissal fair but whom the employer decides not to dismiss. Let us say that employees found guilty of fraud have consistently been dismissed in a particular company

45 NUMSA v Hendor Mining Supplies (A Division Marschalk Beleggings) (Pty) Ltd (2003) 24 ILJ 2171 (LC).

46 Hendor Mining Supplies (2007) supra par 39.

47 Supra.

48 TSI Holdings supra par 8.

49 TSI Holdings supra par 38. 
for many years but in one case the employer decides that in a particular case he will not dismiss the employee because of some unacceptable reason such as that he is white and the others who had been dismissed for similar offences were black. ${ }^{50}$ Let us assume that the loss resulting from such fraud for the employer is a million rand. It seems that in such a case, if the employee was guilty of such serious misconduct that would, quite clearly, be a fair reason for his dismissal. In such a case it may well be that, if there was a disciplinary inquiry and such employee was found guilty of such serious misconduct but was not dismissed on such unacceptable grounds as racist grounds, a demand that the employer dismiss such employee cannot be said to be a demand for the employer to act unfairly. It may well be that in such a case it is arguable - and I put it no higher than that - that such a demand may form part of a protected strike."51

If the targeted manager's dismissal was to be sustained as being fair and, therefore, not abridging his right not to be dismissed unfairly, it goes without saying that there must be evidential foundation for alleged use of racial invective. In the instant matter, there was no admissible evidence because the persons who were with the offending manager when he allegedly made the offensive remarks and who allegedly heard the remarks did not depose to any affidavits. ${ }^{52}$ If the employees persisted with the demand that the employer dismiss the manager in violation of his rights provided for in section 185 read with section 188 of the LRA, "he might well have been able to approach a court or forum of competent jurisdiction and sought either a declarator that such dismissal, if effected, would be unfair and in breach of sections 185 and 188 or he could have sought an interdict restraining the appellant from dismissing him". ${ }^{53}$ Provided that the usual requirements for an interdict could be met, and an interdict is granted, the employer would definitely be entitled to refuse to comply with the employees' demand. ${ }^{54}$ It also means that the union and its members could not persist with the demand at that stage as the demand would in effect be requiring the employer to act in contempt of an order of court and, therefore, to commit the crime of contempt. In short, the demand made by the respondents to the appellant fell "outside the category of demands that can be supported by a concerted refusal to work, retardation or obstruction of work envisaged in the definition of the word 'strike' in section 213 of the Act". 55

Returning to the National Lotteries Board case, ${ }^{56}$ Zondo $\mathrm{J}$ found that the union and employees did not demand the CEO's dismissal, but strongly recommended his dismissal. ${ }^{57} \mathrm{~A}$ reading of the petition disclosed that there was no justification for the suggestion that the employees demanded that the CEO be dismissed without a hearing. The board could have put the

50 This brings to the fore the tension between consistency or the parity principle and progressive discipline in determining an appropriate sanction. See e.g., Absa Bank v Naidu (2015) 36 ILJ 602 (LAC); Seakamela and Magalies Water (2014) 35 ILJ 1132 (CCMA); NUM v Amcoal Colliery t/a Arnot Colliery [2008] 8 BLLR 869 (LAC).

51 TSI Holdings supra par 39.

52 TSI Holdings supra par 44.

53 TSI Holdings supra par 47.

54 TSI Holdings supra par 47.

55 Bader Bop (Pty) Ltd v NUMSA (2002) 23 ILJ 104 (LAC) par 40-50; NUMSA v Bader Bop (Pty) Ltd (2003) 24 ILJ 305 (CC) par 24.

56 Supra.

57 National Board Lotteries supra par 199. 
allegations to him to deal with before deciding to dismiss him if there was a fair reason for his dismissal. The petition also revealed that the employees did not threaten to stop working after 30 June if the CEO was still employed in that capacity. They held back from stating what would happen if he was still the CEO after 30 June 2008.

\section{6 $\begin{array}{ll}\text { GENDERED } & \text { PRECARIOUSNESS } \\ \text { DISCRIMINATORY RETRENCHMENTS }\end{array}$}

The case of Chuma $^{58}$ presents the opportunity to consider some of the interesting problems raised by the dismissal of 28 female security guards, ostensibly for operational reasons as a result of pressure exerted by the client of the temporary employment service. The reason was that Chuma Security Services' client, Metrorail, requested it to employ fewer women and more men as security guards. Chuma was presented with a Hobson's choice: either it could retain reliable female security officers and risk losing the Metrorail contract, or it would have to terminate the services of the targeted employees, thereby contravening section 187(1)(f) of the LRA by unfairly discriminating against the female employees on the basis of gender. In order to assuage the client, and at the same time avoid losing a lucrative contract, Chuma chose to retrench the female security guards.

\section{Did the demand for removal of female guards have legitimate foundation?}

If not siblings, Nape $v$ INTCS Corporate Solutions (Pty) Ltd ${ }^{59}$ and Chuma are certainly first cousins. In Nape, the essential dispute concerned the dismissal by a labour broker of an employee at the behest of a third party. The employee had sent an email containing offensive material at the client's premises and the client demanded the removal of the employee. It was a term of the contract between the client and the labour broker that the client could demand the removal of an employee for any reason whatsoever. In defending an unfair dismissal claim brought by the employee, the employer relied on Lebowa Platinum Mines ${ }^{60}$ and argued that there was nothing it could do after the client demanded the removal of the employee. It also argued that in the circumstances it could legitimately invoke the provisions of section 189 of the LRA as it had very little bargaining power with the client. The Labour Court found that the employer and the client could not structure their contractual relationship in a way that would effectively treat employees as commodities to be passed and traded at the whims and fancies of the client and that the contractual relationship should not be structured in a way that undermines the employee's constitutionally guaranteed rights. In holding the client's demand illegitimate, the Labour Court invoked the following rationale:

58 Supra.

59 (2010) 31 ILJ 2120 (LC) (Nape). See Nkhumise "Dismissal of an Employee at the Instance of a Client: Revisiting Nape v INTCS Corporate Solutions (Pty) Ltd in the Context of the Labour Relations Amendment Act 6 of 2014" 201620 LLD 106.

60 Supra. 
"An illegal demand can never found the basis to justify a dismissal based on operational requirements just as it cannot form the basis of a lawful strike. By the same token s189 cannot be used to disguise the true reason for dismissal." 61

On the facts in Chuma, two things are immediately notable about the unlawfulness of the demand for removal of female security personnel. The first is that its focus on female employees constitutes a serious encroachment on the right to equality, dignity and fair labour practice as amplified in the Employment Equity Act (EEA) ${ }^{62}$ and the LRA. Indeed, "Chuma conceded that, but for the fact that the applicants were women, their employment would not have been terminated. They were dismissed to make way for male security officers."63 The second is the relative lack of substantive reasons for the dismissal of the affected employees. To put it bluntly, the female security officers were good workers because "they did not miss work and they did not attend work with a hangover". ${ }^{64}$ Compared to the road rage killer in Kroeger $v$ Visual Marketing, ${ }^{65}$ there was no fault or degree of moral turpitude that could be attributed to the retrenched female security officers aside from the fact that the call for their replacement was predicated on their gender. To this may be added that Chuma was alive to the fact that the demand by Metrorail that resulted in the dismissal of the applicants was unlawful and in fact contravened the equality laws. ${ }^{66}$ This means that the dismissals were automatically unfair as envisaged by section $187(1)(f)$ of the LRA.

\section{The tension between the third-party demand and the norm of accountability}

A reading of Chuma $^{67}$ leads one to an inevitable tension between the thirdparty demand for replacement of female security officers and the norm of accountability. Foremost, PRASA/Metrorail as an organ of state is bound to uphold and respect fundamental rights while acting both ethically and accountably. ${ }^{68}$ The constitutional tri-norms of accountability, responsiveness and openness are embodied in section $1(d)$ of the Constitution. Apart from playing a focal role in adjudication, ${ }^{69}$ the accountability norm ${ }^{70}$ closely

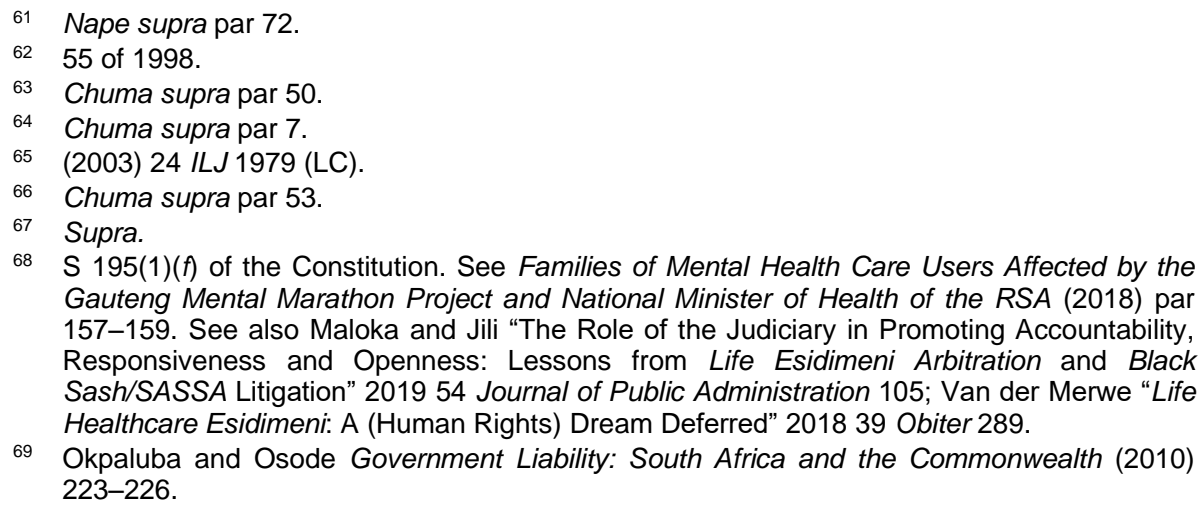
Gauteng Mental Marathon Project and National Minister of Health of the RSA (2018) par 157-159. See also Maloka and Jili "The Role of the Judiciary in Promoting Accountability, Responsiveness and Openness: Lessons from Life Esidimeni Arbitration and Black Sash/SASSA Litigation" 201954 Journal of Public Administration 105; Van der Merwe "Life Healthcare Esidimeni: A (Human Rights) Dream Deferred" 201839 Obiter 289.

69 Okpaluba and Osode Government Liability: South Africa and the Commonwealth (2010) 223-226. 
intersects with the protection and advancement of fundamental rights of women ${ }^{71}$ and children. ${ }^{72}$ Carmichele $v$ Minister of Safety and Security ${ }^{73}$ and $K v$ Minister of Safety and Security ${ }^{74}$ have given authoritative views on the norm of accountability when fundamental rights are at stake. Clearly, a demand for the removal of female security guards is at variance with the norm of accountability. It involved gendered harms ${ }^{75}$ and encroachment on the fundamental rights of vulnerable employees in the wake of incidents of sexual assaults while on duty. In addition, it cannot be said that the posture adopted by Metrorail and Chuma accords with the spirit, objects and purport of the Bill of Rights.

In the same breath, it is also unethical as it reinforces intersecting patterns of race and gender discrimination in society. ${ }^{76}$ It is widely accepted that black women in South Africa have suffered multidimensional oppressions

70 Okpaluba "Delictual Liability of Public Authorities: Pitching the Constitutional Norm of Accountability Against the 'Floodgates' Argument" 200620 Speculum Juris 248.

71 See e.g., Tshabalala v S 2020 (3) BCLR 307 (CC); Omar v Government of the RSA 2006 (2) SA 289 (CC); Bhe $v$ The Magistrate, Khayelitsha 2005 (1) SA 563 (CC).

72 See e.g., Tshabalala v S; Ntuli v S 2020 (5) SA 1 (CC); Levenstein v Estate of the Late Sydney Frankel 2018 (2) SACR 283 (CC); Teddy Bear Clinic for Abused Children v Minister of Justice and Constitutional Development 2014 (2) SA 168 (CC); HOD, Department of Education, Free State Province v Welkom High School 2014 (2) SA 228 (CC); Bannatyne v Bannatyne (Commission for Gender Equality as Amicus Curiae) 2003 (2) SA 363 (CC).

732001 (4) SA 938 (CC).

742005 (6) SA 419 (CC). See also Roederer "The Constitutionally Inspired Approach to Vicarious Liability in Cases of Intentional Wrongful Acts by the Police: One Small Step in Restoring the Public's Trust in the South African Police Services" 200521 SAJHR 575.

75 The essence of "gendered harm" theory is that the quality of women's suffering is different from that of men. Conaghan ("Gendered Harms and the Law of Tort: Remedying (Sexual) Harassment" 199616 OJLS 407 407) elucidates: "From a societal perspective, feminists have argued that women suffer particular harms and injuries as women: their experience of pain and injury is distinguishable, to a large extent, from the experience of men. This claim has at least two dimensions. On the one hand pregnancy and childbirth, menstrual and/or ovulation pains are obvious examples of gender-specific "harms". Men do not/cannot experience these traumas directly. On the other hand, the concept of gendered harm can also embrace those harms which, although not exclusive to women in any biological sense, are risks which women are more likely to incur than men - the risk of rape, incest, sexual harassment, spousal abuse or, more contentiously, the risk of harmful medical intervention. Although men can and do experience these harms also, they are, arguably, less likely to do so. Moreover, in so far as they do incur such risks, their experience of them as men is different and distinct from how they are experienced by women."

76 Brink $v$ Kitshoff NO [1996] 6 BCLR 752 (CC) par 44. This also brings to the fore the grotesque facts of Ntsabo $v$ Real Security (2003) 24 ILJ 2341 (LC) and Moatshe $v$ Legend Golf \& Safari Resorts Operations (Pty) Ltd [2014] 12 BLLR 1213 (LC). See generally, Zalesne "The Effectiveness of the Employment Equity Act and the Code of Good Practice in Reducing Sexual Harassment" 200117 SAJHR 507 509; Rycroft and Perumal "Compensating the Sexually Harassed Employee" 200425 ILJ 1153; Le Roux "Sexual Harassment in the Workplace: Reflection on Grobler v Naspers" 200425 ILJ 1897; Whitcher "Two Roads to an Employer Liability for Sexual Harassment: $S$ Grobler v Naspers Bpk en Ander and Ntsabo v Real Security CC" 200425 ILJ 1907; Mukheibir and Ristow "An Overview of Sexual Harassment: Liability of the Employer" 200627 Obiter 248; Whitear-Nel “'Do You Want a Lover Tonight?' Simmers v Campbell Scientific Africa (Pty) Ltd (2016) 37 ILJ 116 (LAC)" 201738 ILJ 769; McGregor "'Do You Want a Lover Tonight?' Does This Question Constitute Sexual Harassment? Simmers $v$ Campbell Scientific Africa (Pty) Ltd (2014) 35 ILJ 2866 (LC)" 201679 THRHR 324. See also "Sexual Harassment: Why Do Victims So Often Resign? E v lkwezi Municipality 201637 ILJ 1799 (ECG)" 201922 PER/PELJ 1. 
and have been marginalised by virtue of being both black and female. ${ }^{77}$ Examined through the prism of critical race theory, ${ }^{78}$ the retrenchment of female security guards as a result of mounting third-party pressure more than typifies the precariousness of triangular employment relationships; it underscores the porous boundary between gendered vulnerability and the double jeopardy of subordination: female and black. Indeed, precariousness is inherently gendered and racialised. ${ }^{79}$

\section{The intersection of public authority liability and the demand for replacement of female security officers}

As already noted, cogent reasons exist for denigrating the demand for removal of female security personnel. One might ask: how, if the demand is both unlawful and discriminatory, is there a scope for finding that management's call makes sense and is indeed rational? The answer lies in the South African law of public authority liability, a site of burgeoning jurisprudence. ${ }^{80}$

Behind Metrorail's insistence on the removal of female security officers, lie business imperatives aligning with the pressing concern for rail commuter safety. Its hardened attitude can be ascribed to the freighted issue of public authority liability. To the extent that this is true - that is, to the extent that the demand for the replacement of female security officers was to enhance safety and minimise the risk of vicarious liability - it taps into important reality. The apex court in Rail Commuters Action Group v Transnet Ltd t/a Metroraiß $\beta 1$ recognised that the rail commuter services carry a positive obligation to implement reasonable measures to ensure the safety of rail commuters who travel on the trains, and that such obligation should give rise to delictual liability where there is a risk of harm to commuters resulting from falling out of the crowded trains running with open doors, which is foreseeable.

It is widely acknowledged that rail commuter services carry a positive obligation to implement reasonable measures to ensure the safety of all

77 See generally, O'Regan "Equality at Work and the Limits of the Law: Symmetry and Individualism in Antidiscrimination Legislation" 1994 AJ 64 65; Romany "Black Women and Gender Equality in a New South Africa: Human Rights Law and the Intersection of Race and Gender" 201721 Brook J Int. L 857 861. For an historical account of intersectionality between race, class and inequality, see Seekings and Nattras Class, Race and Inequality in South Africa (2006).

78 For a sampling of critical race theory research, see Crenshaw "Demarginalizing the Intersection of Race and Sex: A Black Feminist Critique of Anti-Discrimination Doctrine, Feminist Theory and Anti-Racist Politics" 19891 University of Chicago Legal Forum 139; "Mapping Margins: Intersectionality, Identity Politics, and Violence Against Women of Colour" 199143 Stan LR 1241 and "Twenty Years of Critical Race Theory: Looking Back to Move Forward" 201143 Conn LR 1253.

79 Cooper "Women and the Right to Work" 200925 SAJHR 573 578-579.

80 Okpaluba "The Law of Bureaucratic Negligence in South Africa: A Comparative Commonwealth Perspective" 2006 AJ 117.

812005 (2) SA 359 (CC) (Rail Commuters Action Group) par 84. 
commuters who travel on the trains. ${ }^{82}$ The primary responsibility for ensuring that measures are in place, irrespective of whether a service provider is assigned to implement them, rests with Metrorail and the Commuter Corporation. ${ }^{83}$ Seen through the prism of public authority liability, it is submitted that Metrorail's hostile approach is not necessarily underpinned by antipathy towards the deployment of female officers per se - the problem was their alleged ineffectiveness. If regard is had to the risk of delictual liability, the stance adopted by Metrorail makes perfect sense. Therefore, the insistence on a change of security personnel in circumstances where services were inadequately performed was simply to ensure that constitutional and statutory obligations are fulfilled.

\section{How serious and imminent must the threat be?}

The other important element for an employer to establish is that the third party's threat (if its demand is not met) was real or serious. In this regard, the employer must lead convincing evidence as to the outside pressure it was under as well as demonstrate that non-compliance would have brought the company to a standstill resulting in irreparable harm. ${ }^{84} \mathrm{~A}$ mere inconvenience would not be enough. In many instances, the economic consequences to the employer should a third-party threat materialise would not be challenged. The decisive question is whether the employer properly assessed the threat as being sufficiently serious and imminent for it not to be overlooked, and for it to take a drastic step in respect of the offending employee's position?

Although Chuma appreciated that the client's request lacked substance and was patently unlawful, it contended that the threat of losing the Metrorail contract loomed large. It should be remembered that the underlying rationale of outsourcing is that the outsourcer is in a position to bring in a specialist service provider and to ensure quality of service via the terms of the outsourcing contract (so-called "management by contract") and the threat of non-renewal of that contract if such services are not adequately performed. ${ }^{85}$ Defying the client meant non-renewal of the contract. Metrorail wanted fewer female security officers and, as service provider, Chuma has to do as demanded by the client. ${ }^{86}$ The threat of non-renewal of the monthly contract

82 Reporter "Prasa Worker in Stable Condition After Attack on CT Northern Line" https://ewn.co.za/2018/02/08/prasa-worker-in-stable-condition-after-attack-on-ct-northernline (accessed 2018-07-19).

83 Rail Commuters Action Group supra par 73-78 and 84; Mashongwa v PRASA 2016 (3) SA 528 par 52; PRASA v Mobil [2017] 4 All 648 (SCA) par 32-34. See Okpaluba and Osode Government Liability 225-226.

84 For e.g., in ABI (Pty) Ltd v Jonker (1993) 14 ILJ 1232 (LAC), the court was not convinced that a threat of a national strike by 1.2 million workers and its likely effect on the company's operations was sufficient to justify the dismissal of the targeted manager. In that case, FAWU had demanded that Jonker be dismissed because of past affiliations with the security police and his involvement in the assault of union members. The fact that termination would ensure normal operations was found not to be compelling justification; the employer was required to satisfy the court that the problem created by the third party could only be solved by terminating the employee's services. See also Mnguni v Imperial Systems (Pty) Ltd t/a Imperial Distributors (2002) 23 ILJ 492 (LC).

85 Grogan "Outsourcing Workers: A Fresh Look at Section 197" 200016 EL 1524.

86 Chuma supra par 8 
could not be taken lightly because "the e-mail from Blom had been copied to senior people within PRASA, who had the powers to terminate the contract". ${ }^{87}$ With the threat of the Metrorail contract cancellation in mind, Chuma acted with deliberate speed in informing PRASA that 50 female employees would be retrenched.

Although the threat of non-renewal of contract was imminent, the question that may be asked is: what measures are at the disposal of a labour broker when a client demands unlawful removal of an employee? Answering this question, the Labour Court in Nape ${ }^{88}$ expressed the view that:

"[t]he labour broker is in fact not powerless to resist its client's attempt to wield its bargaining power in a way which undermines the fundamental rights of employees. The labour broker is entitled to approach a court of law to compel the client not to insist upon the removal of an employee where no fair grounds exist for that employee to be removed." 89

This is what Chuma ought to have done as it rightly conceded that the client's demand infringed upon employees' fundamental rights. The point is aptly driven home by the court in Nape as follows:

"The respondent labour broker could have accordingly resisted the client's attempts to invoke clauses in its contract with the client which undermined the applicant's rights. It was unfair of it not to do so before invoking its right to terminate the contract of employment for operational requirements and also because the demand of the client was unlawful and unfair." 90

If Metrorail terminated the contract because of Chuma's failure to comply with its unlawful demand, the labour broker could approach the Labour Court for urgent relief. This brings to the fore a perennial headache for the Labour Court. ${ }^{91}$ The shores of the Labour Court's urgent roll are littered with wrecks from unsuccessful declaratory and interlocutory applications in which the court is asked to intervene in disciplinary proceedings that were hardly out of the starting block and certainly not finalised..$^{92}$ The Labour Court's orthodox position is clear - namely, that courts will only intervene on an urgent basis if truly exceptional circumstances are shown to exist - for instance, where the constitutional rights of an employee are being "trampled". 93

It is appropriate to refer to some striking illustrations where such exceptional circumstances were found to exist. A proper practical illustration is the decision in Minister of Labour $v P A^{94}$ itself, which dealt with the

\footnotetext{
Chuma supra par 23.

Supra.

Nape supra par 77.

Nape supra par 86

91 Cohen "Precautionary Suspensions in the Public Sector: MEC for Education, North West Provincial Government v Gradwell (2012) 33 ILJ 2012 (LAC)" 201334 ILJ 1706.

92 See Maloka "Interdicting an In-House Disciplinary Enquiry With Reference to Rabie $v$ Department of Trade and Industry 2018 ZALCJHB 78" 201944 JJS 10; Maloka and Peach "Is an Agreement to Refer a Matter to an Inquiry by an Arbitrator in terms of Section 188A of the LRA a Straightjacket" 201649 De Jure 368. This aspect of labour dispute resolution continues to generate countless cases: Matlala v Greater Tzaneen Local Municipality [2020] ZALCJHB 2; Long v SA Breweries (2019) 40 ILJ 965 (CC).

93 Bargarette $v$ PACOFS 2007 ZALC 182.

94 (2017) 38 ILJ 1075 (LAC).
} 
revocation of an employee's designation as a Registrar of Labour Relations in terms of the LRA, and his resultant removal from that position, for reasons that were entirely irrational and invalid and where there was in reality no alternative remedy. Another illustration is the well-known matter of Solidarity $v S A B C,{ }^{95}$ which concerned the dismissal and victimisation of reporters for being critical of policy decisions by the SABC as a public broadcaster, which conduct violated the constitutional rights of the employees, and even infringed on the right of the public to be properly informed. The situation in Chuma ${ }^{96}$ is a classic example of exceptional circumstances that may warrant the Labour Court to grant an interim order restraining a party from exercising contractual power in a manner that impairs the fundamental rights of female employees.

It is clear from eminent authorities ${ }^{97}$ that the general thrust of section 8(2) of the Constitution is not to obstruct private autonomy or to impose on a private party the duties of the State in protecting the Bill of Rights. Put simply, the requirement is rather that private parties not interfere with or diminish the enjoyment of a right. ${ }^{98}$ If Metrorail terminated the contract with Chuma as a result of the latter's failure to remove female security personnel, such a measure would negatively infringe upon the rights of affected employees. Given that Metrorail is an organ of state, the intensity of the obligation not to negatively diminish constitutionally protected rights is greater.

\section{Did the employer make reasonable endeavours to dissuade the third party to drop its demand?}

Having regard to the pertinent facts in Chuma, ${ }^{99}$ could it be said that management pressed the fruit while still green and expected it, unreasonably, to ripen? To put it differently, was the dismissal of female security officers precipitate? The question whether management had made efforts to persuade the third party to abandon its demand for the employee's dismissal would depend on the facts of each case. In most cases, the employer would be constrained by the nature of the misconduct that gave rise to the demand or the unreasonable conditions put by the third party as a precondition for withdrawing its demand. ${ }^{100}$

95 (2016) 37 ILJ 2888 (LC) par 65-66. See also Chubisi v SABC (SOC) (2021) 42 ILJ 395 (LC).

96 Supra.

97 See Jaftha $v$ Schoeman 2005 (2) SA 140 (CC) par 33-34; Rail Commuters Action Group supra par 68-71; Minister of Health v TAC 2002 (5) SA 721 (CC) par 46.

98 Governing Body of the Juma Musjid Primary School v Essay NO [2011] 8 BCLR 761 (CC) par 58.

99 Supra.

100 In Govender supra, the workforce's condition for abandoning their demand for dismissal proved unacceptable to the employer. Black employees would only accept the employee's continued employment with the company if it reinstated a black employee who had been dismissed for assaulting an Indian employee three years earlier. This would have opened a floodgate of claims for reinstatement by ex-employees who were dismissed for misconduct. Furthermore, a transfer was proposed by management but rejected by the workers on the basis that the problem itself would be transferred. 
It needs to be stressed that the paramount consideration in persuading the third party to abandon the demand for dismissal is to avoid an injustice to the targeted employee. The facts in Chuma reveal that the employer was focused on not jeopardising its commercial relationship with the client. What is more, Chuma's representative in his testimony felt that "he was to be applauded because he has succeeded in getting Metrorail to back down on the big number of female security officers that they wanted replaced by male security officers." 101 Furthermore, the point must be made that Chuma had ammunition in resisting the unlawful, unjustified and discriminatory demand made by Metrorail. The terms of the contract with PRASA did not require the deployment of male security guards. This all points distinctly to the fact that no steps were taken by Chuma to persuade Metrorail to drop its demand; and it neither investigated the specific incidents that Metrorail relied upon in support of its demand for the removal of female security officers, nor attempted to secure alternative positions for the dismissed employees. ${ }^{102}$ The rationale for the dismissal was to placate the client and safeguard commercial interests. Steenkamp J explains:

"There can be no debate that termination of the employment of the applicant caused injustice to these employees, who were not at fault. They had done nothing wrong. Chuma ought to have considered this factor. There is no evidence that the factor was considered and if it was, what weight, if any, it had on the decisions ultimately made by the respondent. Against those facts, the test of necessity or fairness has not been passed by the respondent.

Chuma did not have a fair reason for dismissing the applicants." 103

In sum, the dismissal of female security officers for operational reasons was simply a ruse.

\section{Were alternatives to dismissal genuinely explored?}

At what point does dismissal become appropriate and what alternatives should an employer have explored? These considerations are central to an assessment of the fairness of dismissal at the behest of a third party. It has been suggested that fairness in this context does not require that the employer should exhaust every possibility to avoid termination but that it should act reasonably and bona fide and take into account alternatives to its intended course of conduct. Indeed, there is no hard-and-fast rule.

The termination of an employee's services actuated by pressure imposed upon management sits uneasily within the realm of dismissal for operational reasons. Where the demand for dismissal is attributable to the targeted employee's own reprehensible conduct, ${ }^{104}$ then fault-based dismissal arises

\footnotetext{
Chuma supra par 8.

Chuma supra par 60 and 67.

Chuma supra par 71.

104 In Kroeger, the demand for the employee's dismissal was based on his conduct - namely, the brutal killing and shooting of a black motorist during a road rage incident, coupled with the use of racial slurs at work.
} 
for operational reasons ${ }^{105}$ as opposed to statutory dismissal for operational reasons. ${ }^{106}$ The fault-based termination for operational reasons prompts a closer scrutiny of management's motives and the actuating causes. This is more so when there is no culpable conduct on the part of the affected employee(s).

In Chuma, the decision to retrench was presented as a fait accompli. Chuma ignored the statutory guidelines in section 189. Pointers include that it avoided NUMSA despite the fact that the verification process had established that it had 49,5 per cent membership. In effect, NUMSA was not afforded an opportunity to put proposals on the table on possible measures to avoid dismissals. Therefore, it cannot be said that the dismissal could not have been avoided. The Labour Court cannot be faulted for holding that the retrenchment exercise embarked upon was both substantively and procedurally unfair.

\section{Gendered and gendering dimension of precariousness}

Leaving aside the obvious problem of employment vulnerability for a moment, from a critical feminist standpoint, Chuma illustrates in a specific way the re-production of gendered violence. Also arising is the spatial and temporal distancing through which violence is constructed. The posture assumed by the temporary employment service and the client is reflective of a masculine approach to human security. Equally, it is important to note that the demand for removal and subsequent retrenchment of female security officers casts a spotlight on how vulnerability to violence is problematised, and what kind of gendered meanings are thereby produced, mobilised and reinforced.

105 In ERPM supra 1150A-B, a distinction was drawn between normal dismissals for operational reasons and "fault" based dismissal for operational requirements. Cameron JA (as he then was) explained: "These dismissals at the behest of third parties were not, however, as in Atlantis Diesel Engines, the product of operational reasons arising from serious financial difficulties in consequence of a declining market-share. Nor were they retrenchments arising from 'outsourcing' of a portion of the enterprise's business. Nor again, were they the product of reorganization or technological developments or electronic supersession of previous employee functions. There was in fact work for these workers to do. It was urgent that they should return it. The company could, at least in the foreseeable short term, pay them to do it. They were not dismissed because their job had disappeared. They were dismissed because the company was unable to guarantee their safety at the premises because of ethnic hostility in the workplace." The jurisprudential foundations for sui generis fault-based dismissal for operational reasons is the touchstone case on derivative misconduct, Chauke v Lee Service Centre CC t/a Leeson Motors (1998) 19 ILJ 1441 (LAC) par 12. In treating the misconduct as a collective issue, Cameron $\mathrm{J}$ explained that it is justified where one of only two employees is known to have been involved in 'major irreversible destructive action' but management is unable to pinpoint which of them is responsible for the act. In this instance, the employer may be entitled to dismiss both of them, including the innocent one, where all avenues of investigation have been exhausted. The rationalisation here is that of operational requirement - namely, that action is necessary to save the life of the enterprise. See Maloka "Derivative Misconduct and Forms Thereof: Western Platinum Refinery Ltd v Hlebela 2015 ILJ 2280 (LAC)" 201619 PER/PELJ 1.

$106 \mathrm{~S} 189$ of the LRA. 
Returning to Chuma, Metrorail raised the issue of increased crime on sites serviced by Chuma and surmised that this was due to the deployment of mostly female security officers, "who according to Metrorail could not arrest crime". ${ }^{107}$ This was particularly true with respect to two incidents involving female guards. In one incident, a female security officer was sexually assaulted while doing cable patrol in the company of a male security officer. The other incident involved a female security guard who was attacked whilst in a guardroom on Metrorail's premises.

It can be recalled that there was no serious case of misconduct or incapacity linked to the female security officers that could perhaps justify Metrorail's demand for drastic action. On the contrary, female security guards were at a great risk of sexual assault while on patrol. The vulnerability of female security officers to violence is illustrative of "a disturbingly dark side to the often-stated miracle of our constitutional democracy." 108 Against the backdrop of intolerable levels of gender-based and sexual violence, ${ }^{109}$ incidents of sexual assault involving female security officers on duty in a high-risk environment were fairly routine. With the police failing to contain a gendered security crisis in the Western Cape, ${ }^{110}$ and Cape Town dubbed South Africa's real crime capital, ${ }^{111}$ it can be argued that Metrorail was taking cheap shots by blaming female security guards for failing to arrest crime ${ }^{112}$ South Africa's notoriety for gender-based violence hardly needs explanation.

Metrorail's keenest objections about the ineffectual female security officers and the demand for the deployment of male security guards demonstrates how gender impinges significantly on human security. In addressing the client security concerns, Chuma distanced itself from the plight of its reliable female workforce. This underscores the way in which "security" is still dominantly conceived as relating primarily to the ruptures of normal life rather than violence embedded within it. ${ }^{113}$

107 Chuma supra par 6.

108 Per Van der Westhuizen J in Loureiro v Imvula Quality Protection (Pty) Ltd 2014 (3) SA 394 (CC) par 2.

109 See Gender-Based Violence (GBV) in South Africa: A Brief Review April 2016; Maloka "Rape Shield in the Wake of S v M" 200418 Speculum Juris 264 and "Childhood SexualAbuse Narratives: Taking Their Place in a Long Line of 'Gendered Harms' and 'Mirrored Silence"' 200620 Speculum Juris 78.

110 See Commission of Inquiry Into Allegations of Police Inefficiency in Khayelitsha and a Breakdown in Relations Between the Community and Police in Khayelitsha Toward a Safer Khayelitsha (August 2014).

111 See Nicolson "National Crime Statistics Offer Only Cursory Indicator To Understand Crime" (2017-08-22) Daily Maverick https://ww.dailymaverick.co.za/.../2017-08-22-urban-crime-inthe-cities-report; Staff Writer "Cape Town is South Africa's Real Crime Capital" 23 August 2017 https://ww.news24.com/SouthAfrica/.../crimestats-western-cape-is-the-murder-centre (accessed 2018-04-18)

112 Chuma par 61-62.

113 Marhia Everyday (In)Security/(Re)securing the Everyday: Gender, Policing and Violence Against Women in Delhi (Unpublished PhD Thesis, University College of London) 201214. Generally, Shepherd "Gender, Violence and Global Politics: Contemporary Debates in Feminist Security Studies" 20097 Political Studies Review 208; Fox "Girl Soldiers: Human Security and Gendered Insecurity" 200433 Security Dialogue 465; Gasper "Securing Humanity: Situating 'Human Security' as Concept and Discourse" 20056 Journal of Human 


\section{$7 \quad$ CONCLUSION}

The evolving jurisprudence on the fairness of dismissals at the instance of a third party provides a telling site for appraisal of the extent to which South Africa has come to grips with the complexities of precarity. The article answers a central part of this question by illuminating the difficult tension between employment protection and the constitutional and statutory right not be unfairly dismissed, on the one side, and third-party pressure for dismissal, on the other. More centrally, the tension between the vulnerable position of the targeted employee and the coercive demand of the third party is juxtaposed with the interests and the survival of the enterprise itself.

The cases of ERPM, Lebowa Platinum Mines and TSI Holdings ${ }^{114}$ demonstrate that bigotry is often the driving force behind third-party pressure for dismissal of an offending employee. On closer inspection, the reality is that the workplace remains a centrepoint of contestation, sparking fierce debate about reconciliation, non-racialism, transformation, ${ }^{115}$ and commitment to an open and democratic society based on human dignity, equality and freedom. It is also evident in TSI Holdings that where the demand is for the misconducting co-employee to be subject to a fair disciplinary process, such a demand would constitute a legitimate issue in dispute for purposes of strike action as defined in section 213 of the LRA. In other words, a strike in support of a demand that an offending employee be hauled before a disciplinary hearing would be protected. The factual scenario in National Lotteries Board ${ }^{116}$ is a partial but revealing source of the corporate governance migraine and of malfeasance in public office. This having been said, however, it bears emphasising that the judgment is an important pillar of the evolving accountability jurisprudence.

Chuma ${ }^{117}$ illustrates how violence against women arises out of and contributes to reproducing wider, "multiple intersecting axes of inequality and discrimination". Analysed from the vantage point of a "preservation-throughtransformation" thesis, ${ }^{118}$ attempts to dismantle precariousness at work and

Development 221; Hudson “'Doing' Security as Though Humans Matter: A Feminist Perspective on Gender and the Politics of Human Security" 200534 Security Dialogue 155. 114 Supra.

115 The glaring example, of course is fierce contestation over the validity and implementation of affirmative action and employment equity plans. See e.g., the Barnard litigation in SAPS V Solidarity obo Barnard (2014) 35 ILJ 2981 (CC). See generally, Albertyn "Adjudicating Affirmative Action Within a Normative Framework of Substantive Equality and the Employment Equity Act: An Opportunity Missed" 2015132 SALJ 711; Fergus "Towards Unity-Reconciling Fairness and Rationality in Affirmative Action Disputes" 201536 ILJ 41; Gaibie "Affirmative Action: Concepts and Controversies" 201435 ILJ 2655; Dupper "In Defence of Affirmative Action in South Africa" 2004121 SALJ 187. Contrarian views have been expressed to the effect that affirmative action amounts to reverse discrimination; see Benatar "Justice, Diversity and Racial Preference: A Critique of Affirmative Action" 2008125 SALJ 274; Louw "The Employment Equity Act, 1998 and Other Myths About the Pursuit of 'Equality', 'Equity' and 'Dignity' in Post-Apartheid South Africa (Part 1)” 201518 PER/PELJ 28 and (Part 2) 201518 PER/PELJ 29.

116 Supra.

117 Supra.

118 See Siegel "Why Equal Protection No Longer Protects: The Evolving Forms of StatusEnforcing State Action" 199749 Stan LR 1111 and "The Rule of Love': Wife Beating as Prerogative and Privacy" 1996105 Yale LJ 2117. 
the inequality regime may well improve the material and dignitary circumstances of subordinated workers' groups. Repudiating some of the abusive practices constitute a change in the status quo and further emphasises the continuities between gendered precariousness and the norms of hegemonic masculinities. 